\title{
Temporal variation of Brown and Green Lacewings (Neuroptera: Hemerobiidae and Chrysopidae) collected with McPhail traps from a fruit orchard in Southeast Brazil
}

\author{
Rogéria I. R. Lara ${ }^{1=-\infty}$, Daniell R. R. Fernandes ${ }^{2}$, Francisco J. Sosa-Duque ${ }^{3(\infty)}$, Nicanor T. B. \\ Antunes $^{2 \oplus}$, Sérgio de Freitast, Nelson W. Perioto ${ }^{1 \oplus}$
}

${ }^{1}$ Instituto Biológico, Ribeirão Preto, São Paulo, Brazil. ${ }^{2}$ Instituto Nacional de Pesquisas da Amazônia, Manaus, Amazonas, Brazil. ${ }^{3}$ Universidade Federal Rural da Amazônia, Capitão Poço, Pará, Brazil. IIn memorian.

拝=Corresponding author: rirlara@yahoo.com.br

Edited by: Ivan C. F. Martins

Received: February 01, 2020. Accepted: April 27, 2020. Published: May 29, 2020.

\begin{abstract}
This study was aimed at the identification of the Neuroptera (Insecta) obtained with McPhail traps in an orchard of native and exotic fruits in Jaboticabal, São Paulo, Brazil $\left(21^{\circ} 14^{\prime}\right.$ S / 48 $18^{\prime}$ W). Weekly sampling took place between May 2009 and April 2010.187 specimens of Neuroptera were obtained: Nusalala tessellata (Gerstaecker, 1888) (Hemerobiidae) (176 specimens / 94.1\% of the total), Leucochrysa cruentata (Schneider, 1851) (6 / 3.2\%), Ceraeochrysa cubana (Hagen, 1861), Ceraeochrysa everes (Banks, 1920), Chrysoperla externa (Hagen, 1861), Leucochrysa affinis Freitas \& Penny, 2001 and Leucochrysa rodriguezi (Navás, 1913) (Chrysopidae) (1 / 0.5\%, each species). Nusalala tessellata was the most abundant species, with the highest frequencies recorded in August 2009 and March 2010; such frequencies coincided with the fructification of Vangueria madagascariensis Gmelin (Rubiaceae) and Citrus sinensis (L.) Osbeck (Rutaceae), respectively. The use of McPhail traps can assist in the detection of beneficial insects in agroecosystems and establishment of better sustainable control measures.
\end{abstract}

Keywords: biodiversity, Leucochrysa, nontarget, Nusalala, sampling.

In 2018, Brazil became the third largest fruit producer in the world, behind only China and India (FAO 2018). However, increasing restrictions on the chemical control in fruit crops, awareness of food security as well as phytosanitary and quality restrictions have negatively affected the export of these goods (Melo et al. 2014).

The main threat to fruit production in the country are the fruit flies (Diptera: Tephritidae), one of the most economically significant pests in fruit cultivation, as they feed on the fruit pulp, and make them unsuitable for human consumption and industrialization (Araujo \& Zucchi 2003). Therefore, monitoring the populations of fruit flies in fruit orchards is essential for their management, and the McPhail model trap is recommended for capturing the adult insects (ScOz et al. 2006).

McPhail traps use a wide range of products as baits, which are based on fruit extracts or hydrolyzed protein, and are capable of attracting one or more species of fruit flies (Braga Sobrinho et al. 2002, Thomas 2003). The baits used in these traps are not completely specific for capturing tephritids, and several non-target arthropod groups are also frequently collected such as Lepidoptera, Hymenoptera, Neuroptera, Coleoptera, Hemiptera, Blattaria, Orthoptera, Psocoptera and Arachnida, in addition to other families of Diptera like Sarcophagidae, Phoridae, Tachinidae and Muscidae (Thomas 2003).

Different types of baits allow sampling of different non-target insect groups (Uchida et al. 2006). Thomas (2003) reported many families of natural enemies captured with tephritid attractants, including Tachinidae (Diptera), Chrysopidae (Neuroptera), Braconidae and Ichneumonidae (Hymenoptera).

Only a few Neuroptera records have used McPhail traps: Neuenschwander et al. (1981) reported that Chrysoperla carnea (Stephens, 1836), Anisochrysa flavifrons (Brauer, 1851), Anisochrysa zelleri (Schneider, 1851), Anisochrysa genei (Rambur, 1842), Anisochrysa clathrata (Schneider, 1845), Suarius nanus (McLach, 1893), Brinkochrysa michaelseni (Esben-Petersen, 1928) and Chrysopa septempunctata Wesmael, 1841 (Chrysopidae) and Micromus angulatus (=Eumicromus angulatus) (Stephens, 1836) and Sympherobius pygmaeus (Rambur, 1842) (Hemerobiidae) were attracted by Dacus bait ${ }^{\circledR}$ compound, specific for Bactrocera oleae (Rossi, 1790) (Diptera: Tephritidae). Similarly, Thomas (2003) used baited traps with yeast and Biolure ${ }^{\circledR}$, which attracted three genera of chrysopids: Chrysoperla Steinmann, 1964, Ceraeochrysa Adams, 1982 and Leucochrysa McLachlan, 1868.

Neuroptera comprises about 6,000 described species, grouped into 17 families with worldwide distribution (Aspöck 2002). In agricultural ecosystems, Coniopterygidae, Chrysopidae, and Hemerobiidae stand out, which consist of several species that have the potential to be used in pest control programs (Stelzel \& Devetak 1999). Chrysopidae larvae, as well as larvae and adults of Hemerobiidae are important natural enemies of soft-bodied arthropods, which are considered pests such as aphids and mealybugs, as well as eggs of Lepidoptera (McEwen et al. 2001). Such predators are vulnerable to habitat fragmentation and contamination of the environment by agrochemicals and hence, are considered as bioindicator species (Mansell 2002).

Given the importance of Neuroptera in biological pest control, this study was aimed to evaluate the temporal variation of Chrysopidae and Hemerobiidae species collected using McPhail traps baited with hydrolyzed corn protein, from a native and exotic fruit orchard in the city of Jaboticabal, São Paulo, Brazil.

The survey was carried out in an orchard of native and exotic fruits measuring $6,300 \mathrm{~m}^{2}$ approximately, and located in Faculdade de Ciencias Agrárias e Veterinárias, Universidade Estadual Paulista "Júlio de Mesquita Filho", FCAV-UNESP, Campus Jaboticabal, São Paulo, Brazil (21014'S / 4817'W) (Fig. 1). The orchard belongs to the Active Bank of Germoplasm of that institution, and houses around 130 species of fruits belonging to 33 botanical families (Martins 2013).

The collections were carried out between May 2009 and April 2010, 
totaling 53 samples. For the collections, four yellow-colored McPhailtype plastic traps, produced by Isca Technologies ${ }^{\circledR}$, were supplied with $600 \mathrm{~mL}$ of $3 \%$ diluted corn hydrolyzed protein. The traps were installed about $1.60 \mathrm{~m}$ above the ground, and arranged at least $100 \mathrm{~m}$ apart from each other, in a zigzag pattern inside the orchard (Fig. 1). The captured insects were removed and the attractive bait was replaced once in a week.

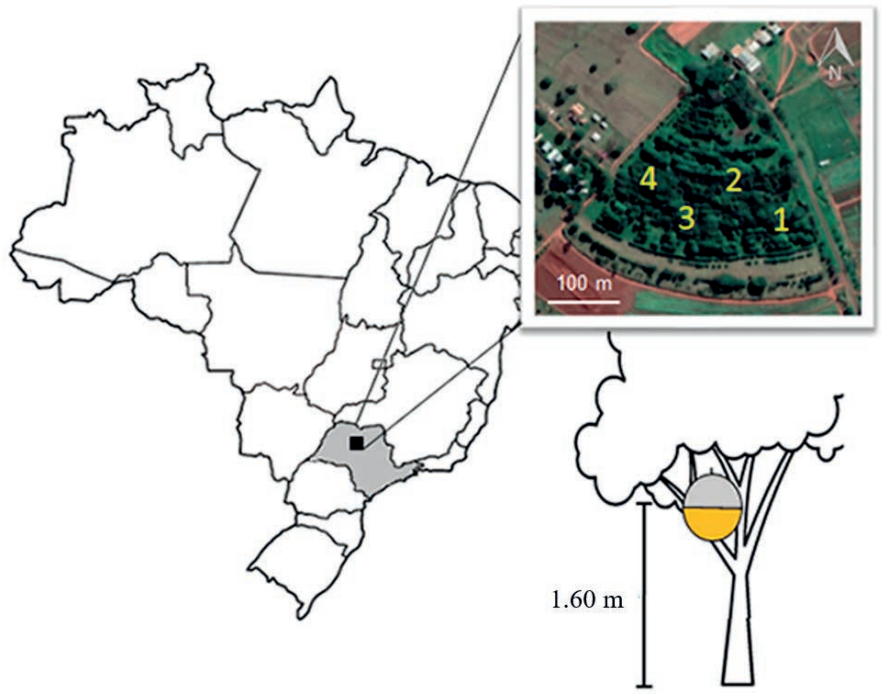

Figure 1. Map of Brazil; in grey the State of São Paulo and, in detail, the studied area and the arrangement of McPhail traps in the fruit orchard in Jaboticabal, São Paulo, Brazil. At lower right, a schematic representation of the location of the traps in the plants.

The trap 1 was set in a Pouteria caimito (Ruiz \& Pav.) Radlk (Sapotaceae) plant, trap 2 in Vangueria madagascariensis Gmelin (Rubiaceae), trap 3 in Eugenia uniflora L. (Myrtaceae) and trap 4 in Citrus sinensis (L.) Osbeck (Rutaceae).

To remove the captured insects, the solution from each trap was filtered through a voile tissue, and the insects retained were transferred to duly labeled plastic bottles containing $70 \%$ ethanol solution $\left(\mathrm{C}_{2} \mathrm{H}_{5} \mathrm{OH}\right)$. These vials were taken to the laboratory where Neuroptera was screened with a stereomicroscope. The specimens of Neuroptera obtained were placed in $2 \mathrm{~mL}$ Eppendorf microtubes, properly labeled; $70 \%$ ethanol solution was used as a preservative.

For the study of the obtained specimens, respective genitalia were prepared according to Sosa et al. (2015). The specific identification of Hemerobiidae was based on Monserrat (2000) and Lara \& Freitas (2002), and identification of Chrysopidae, was based on Adams \& Penny (1985), Freitas \& Penny (2001) and Freitas et al. (2009). The effect of environmental variables (average temperature, relative humidity and rainfall) on the abundance and richness of Neuroptera was assessed by the analysis of linear regression using Vegan package (Oksanen et al. 2015) of the statistical software R (R Development Core Team 2016).

Were obtained 187 specimens of Neuroptera, which belong to two families and seven species. Hemerobiidae and Chrysopidae, both have previous records of capture using McPhail traps baited with hydrolyzed protein (Neuenschwander et al. 1981, Trouvé et al. 2002, Thomas 2003). Nusalala tessellata (Gerstaecker, 1888) (176 specimens / $94.1 \%$ of the total collected) was the only representative of Hemerobiidae. For Chrysopidae, Leucochrysa cruentata (Schneider, 1851) (6 / 3.2\%); Ceraeochrysa cubana (Hagen, 1861), C. everes (Banks, 1920), Chrysoperla externa (Hagen, 1861), Leucochrysa affinis Freitas \& Penny, 2001 and Leucochrysa rodriguezi (Navás, 1913) (1 / 0.5\%, each species ) were found (Tab. 1).

Nusalala tesselata was observed to be more abundant, collected throughout the sampling period, which allows us to infer that this species finds a suitable environment in the fruit agro-ecosystem for its development, and that the McPhail trap baited with corn protein is a useful tool to monitor its presence and fluctuation. It is necessary that in sensitive environments, this type of attractive trap should be used sparingly to avoid creating pressure on populations of endemic, rare species and natural enemies (Thomas 2003).

Other hemerobiids have been sampled with attractive traps and specific baits for fruit flies, such as $M$. angulatus and S. pygmaeus. However, the low number of collected individuals led Neuenschwander et al. (1981) to the conclusion that such hemerobiids were captured in the traps, only when they were searching for water and food, and not because of a possible attraction to the tested bait.

Two population peaks of $N$. tessellata were recorded: first in August 2009 (25 specimens / 13.4\% of the total specimens sampled) and second, in March 2010 (24 / 12.8\%) (Fig. 2), which coincided with the fruiting period of $V$. madagascariensis (trap 2) and $C$. sinensis (trap $4)$, respectively.

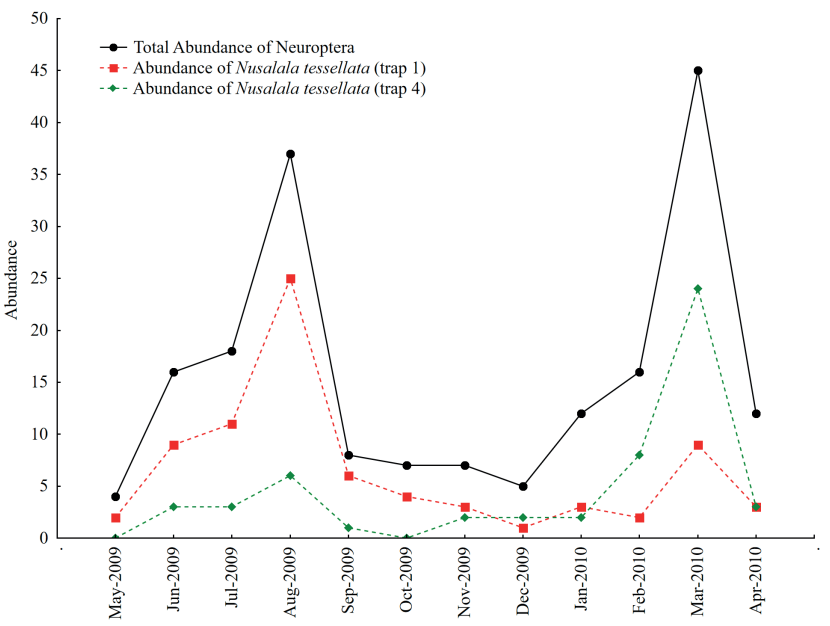

Figure 2. Monthly abundance of Neuroptera and Nusalala tessellata (Gerstaecker, 1888) (Hemerobiidae), collected using McPhail traps from the orchard of native and exotic fruits in Jaboticabal (SP), between May 2009 and April 2010.

The tested environmental variables (average temperature, relative humidity and rainfall) were not related to the abundance of Neuroptera throughout the collection period (Fig. 3).

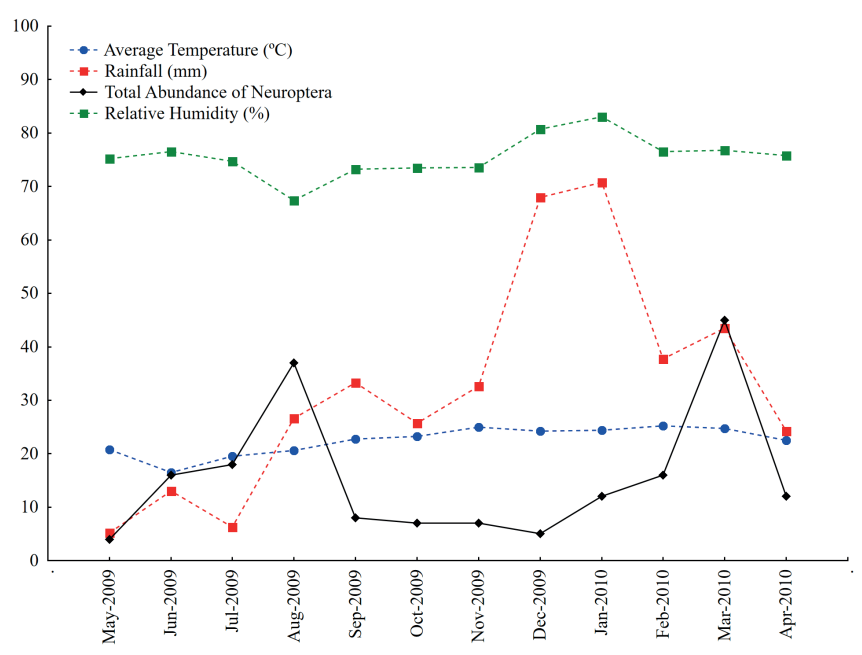

Figure 3. Population fluctuation of Neuroptera collected with McPhail traps from the native and exotic fruit orchard in Jaboticabal (SP), between May 2009 and April 2010, and environmental variables (average temperature, relative humidity, rainfall).

The highest species richness of Neuroptera (four species) was recorded in trap 1, which was fixed on a $P$. caimito tree whose fruits were heavily attacked by frugivorous flies. Fernandes et al. (2013) reported the attack of Anastrepha serpentina (Wiedemann, 1830) (Tephritidae), Neosilba glaberrima (Wiedemann, 1830), Neosilba zadolicha McAlpine \& Steyskal, 1982, Lonchaea sp. (Lonchaeidae) and Zaprionus indianus Gupta, 1970 (Drosophilidae) in the fruits of $P$. caimito which fell to the ground.

The low frequency of captured chrysopids made it impossible to analyze its population fluctuation. The obtained data only allow us to 


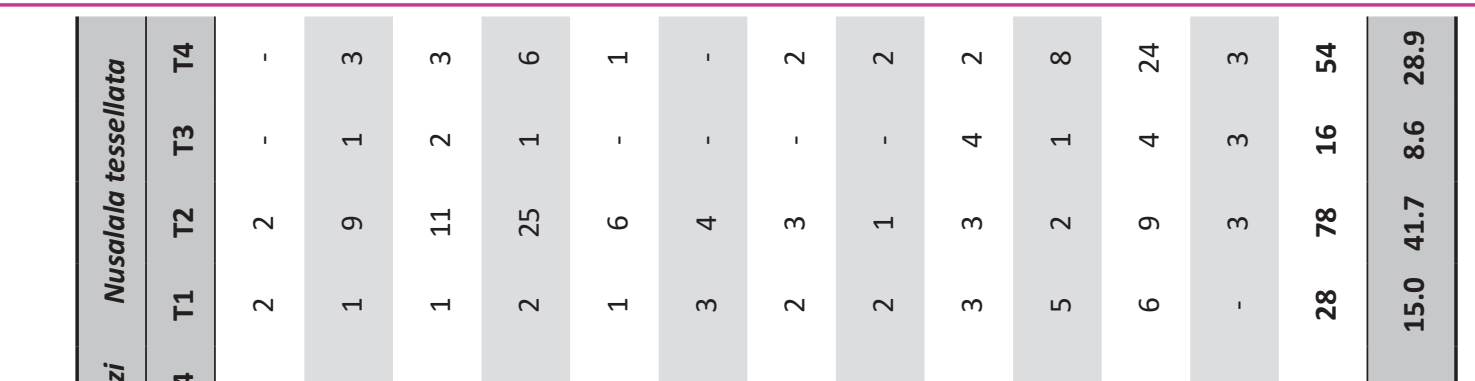


infer that L. cruentata was the most abundant species in the studied fruit orchard. Neuenschwander et al. (1981) collected Chrysopidae using McPhail traps baited with hydrolyzed protein in olive culture and stated that Ch. Carnea, $A$. flavifrons and $A$. zelleri responded positively to the bait. Thomas (2003) used McPhail traps baited with yeast and Biolure $^{\circledR}$, and captured species of Chrysoperla, Ceraeochrysa and Leucochrysa, without quantifying them.

The McPhail traps baited with hydrolyzed corn protein, used mainly for monitoring fruit flies, demonstrated that the neuropterans were attracted to the bait, especially $N$. tessellata. The data obtained allow us to infer that the use of such traps can parallelly assist in the detection of beneficial insects present in agroecosystems, and thus, assist in the establishment of more sustainable control measures, in order to allow the conservation of these entomophages in the field; its suppression, or even elimination by the inappropriate use of pesticides, can lead to the resurgence of secondary pests that were previously controlled by such predators.

New studies that aim to account for the capture of non-target insects by McPhail traps with different baits are as much necessary as the analysis of the attraction potential of these compounds to the entomofauna present in different fruit agroecosystems.

\section{Acknowledgements}

D.R.R.F. thanks Coordenação de Aperfeiçoamento de Pessoal de Nível Superior (CAPES) - financing code 001, and Programa de Capacitação Institucional - PCI / CNPq (process no 312879 / 2019-9).

\section{Authors' Contributions}

D.R.R.F. and N.W.P. planned the sample design and performed the collections. D.R.R.F. identified the orders and separated the Neuroptera. S.F. and F.S.D. identified the Chrysopidae. R.I.R.L. identified the Hemerobiidae. N.T.B.A. performed the statistical analyzes. R.I.R.L., D.R.R.F., N.T.B.A., N.W.P. and F.S.D. wrote the manuscript.

\section{References}

Adams, P. A.; Penny, N. D. (1985) Neuroptera of the Amazon Basin. Part 11a. Introduction and Chrysopini. Acta Amazonica, 15: 413-479 [1987]. doi: 10.1590/1809-43921985153479

Araujo, E. L.; Zucchi, R. A. (2003) Moscas-das-frutas (Diptera: Tephritidae) em goiaba (Psidium guajava L.) em Mossoró, RN. Arquivos do Instituto Biológico, 70(1): 73-77.

Aspöck, U. (2002) Phylogeny of the Neuropterida (Insecta, Holometabola). Zoologica Scripta, 31(1): 51-55. doi: 10.1046/j.0300-3256.2001.00087.x

Braga Sobrinho, R.; Peixoto, M. J. A.; Mesquita, A. L. M.; Bandeira, C. T. (2002) Study on population dynamics of fruit fly species in the State of Ceará. Revista Ciência Agronômica, 33(2): 69-73.

FAO. Organização Das Nações Unidas Para A Agricultura E Alimentação (2018) FAOSTAT. Divisão de estatística. Disponível em: http://www. fao.org/faostat/en/\#data/QC. Acesso em: 20 abr. 2020.

Fernandes, D. R. R.; Vacari, A. M.; Araujo, E. L.; Guimarães, J. A.; De Bortoli, S. A.; Perioto N. W. (2013) Frugivorous flies (Diptera: Tephritidae and Lonchaeidae) and native parasitoids (Hymenoptera) associated with Pouteria caimito (Sapotaceae) in Brazil. Florida Entomologist, 96(1): 255-257. doi: 10.1653/024.096.0139

Freitas, S.; Penny, N. D. (2001) The green lacewings (Neuroptera: Chrysopidae) of Brazilian agroecosystems. Proceedings of the California Academy of Sciences, 52(19): 245-395.

Freitas, S., Penny, N. D.; Adams, P. A. (2009) A revision of the New World genus Ceraeochrysa (Neuroptera: Chrysopidae). Proceedings of the California Academy of Sciences, 60: 503-610.

Lara, R. I. R.; Freitas, S. (2002) Caracterização morfológica de adultos de Nusalala tessellata (Gerstaecker, 1888) (Neuroptera, Hemerobiidae). Revista Brasileira de Entomologia, 46(4): 523-530. doi: 10.1590/S0085-56262002000400005

Mansell, M. W. (2002) Monitoring lacewings (Insecta: Neuroptera) in Southern Africa. Acta Zoologica Academiae Scientiarum Hungaricae, 48(2): 165-173.

Martins, A. B. G. (2013) Collection of fruitful: UNESP Jaboticabal. Revista Brasileira de Fruticultura, 35(4), ii. doi: 10.1590/S010029452013000400001

McEwen, P.; New, T. R.; Whittington, A. E. (2001) Lacewings in the crop environment. Cambridge: Cambridge University Press.

Melo, O.; Engler, A.; Nahuehual, L.; Cofre, G.; Barrena, J. (2014) Do sanitary, phytosanitary, and quality-related standards affect international trade? Evidence from Chilean fruit exports. World Development, 54: 350-359. doi: 10.1016/j.worlddev.2013.10.005

Monserrat, V. J. (2000) Revisión del género Nusalala (Neuroptera, Hemerobiidae). Fragmenta Entomologica, 32(1): 83-162.

Neuenschwander, P; Canard, M.; Michelakis, S. (1981) The attractivity of protein hydrolysate baited McPhail traps to different chrysopid and hemerobiid species [Neuroptera] in a Cretan olive orchard. Annales de la Société Entomologique de France, 17(2): 213-220.

Oksanen, J.; Blanchet, F. G.; Kindt, R.; Legendre, P.; Minchin, P.R.; O'hara, R. B.; Simpson, G. L.; Solymos, P.; Stevens, M. H. H.; Wagner, H. (2015) Package vegan version 2.3:1: Community ecology package. Disponível em: http://cran.r-project.org/web/packages/vegan/ vegan.pdf

R Development Core Team (2016) R: a language and environment for statistical computing. $R$ foundation for statistical computing. Disponível em: http://www.R-project.org.

Scoz, P. L.; Botton, M.; Garcia, S. M.; Pastori, P. L. (2006) Avaliação de atrativos alimentares e armadilhas para o monitoramento de Anastrepha fraterculus (Wiedmann, 1830) (Diptera: Tephritidae) na cultura do pessegueiro (Prunus persicae (L.) Batsh). Idesia, 24(2): 7-13. doi: 10.4067/S0718-34292006000200002

Sosa, F.; Lara, R. I. R.; Martins, C. C. (2015) A new species of Hemerobiella Kimmins (Neuroptera, Hemerobiidae) from Venezuela with notes on the genus. Zootaxa, 4028(3): 421-429. doi: 10.11646/ zootaxa.4028.3.7

Stelzl, M.; Devetak, D. (1999) Neuroptera in agricultural ecosystems. Agriculture, Ecosystems and Environment, 74(1-3): 305-321. doi: 10.1016/S0167-8809(99)00040-7

Thomas, D. B. (2003) Nontarget insects captured in fruit fly (Diptera: Tephritidae) surveillance traps. Journal of Economic Entomology, 96(6): 1732-1737. doi: 10.1603/0022-0493-96.6.1732

Trouvé, C.; Thierry, D.; Canard, M. (2002) Preliminary survey of the lacewings (Neuroptera, Chrysopidae, Hemerobiidae) in agroecosytems in Northern France, with phenological notes. Acta Zoologica Academiae Scientiarum Hungaricae, 48(supl.): 359-369.

Uchida, G. K.; Mackey, B. E.; Vargas, R. I.; Beardsley, J. W.; Hardy, D. E.; Goff, M.; Stark, J. D. (2006) Response of nontarget insects to methyl eugenol, cue-lure, trimedlure, and protein bait bucket traps on Kauai Island, Hawaii, USA. Proceedings of the Hawaiian Entomological Society, 38: 61-71. 